\title{
PROPERTIES OF ALUMINIUM-CERAMIC PHASE COMPOSITES PRODUCED FROM P/M COMPACTS IN HOT FORGING AND EXTRUSION PROCESSES
}

\section{INTRODUCTION}

Powder metallurgy, as a technology of production of high-quality composites, is presently recognized as competitive in relation to conventional methods, mainly foundry practice. Its most important advantage is the possibility of deformation at temperatures much lower than melting point of metallic matrix, which allows to avoid unfavourable chemical reactions occurring at interphase boundaries of components. The proper selection of ingredients, manufacturing method and parameters of its realization allows to avoid segregation resulting from the differences between mass densities or size of ingredients. Additionally, this technology involves low level of waste products. Main disadvantage of a classical powder metallurgy, based on compaction and sintering processes, is a porosity of obtained products. Apart from the group of products for which specified porosity is required (e.g. self-lubricating slide bearings destined for working in dry friction conditions), the occurrence of pores within the material affects its properties unfavourably. It was found in [1] that at volume fraction above 5\% they become the factor determining the properties of products and practically disqualify the product's application as a construction material. This problem can be eliminated by means of combination of powder metallurgy and plastic working processes. As a result, if a proper variant of manufacturing process is realized and the process parameters are selected properly, it is possible to obtain the product showing the density close to that of a solid material, as well as favourable properties resulting from chemical composition, manufacturing method, technological parameters, possible heat treatment etc. [2-4]. One of more interesting materials that are possible to be produced applying the above mentioned method, are aluminium- and aluminium-alloy-based composites reinforced with ceramic phase. Particles, whiskers or fibres are used as a reinforcing phase. Main advantages of these materials are lightness, close-grained struc-

* Ph.D.: Faculty of Metals Engineering and Industrial Computer Science, AGH University of Science and Technology, Krakow, Poland; mwojtasz@metal.agh.edu.pl 
ture, higher level of mechanical properties, corrosion resistance, wear resistance $[5,6]$ as well as stability of the specified properties in elevated or cyclically variable working temperatures [7]. The application of these materials covers mainly automotive industry, aircraft industry and recreation industry [8].

During the design of chemical composition and forming technology for an aluminiumceramic type composite, the information about its utilization is very important. In many cases the forming technology of a product results from its shape. However, it is often possible for the designer to decide about the method of manufacturing. For example, depending on the employed manufacturing method, type and volume fraction of reinforcing phase as well as the method of its introduction into the matrix, the product may exhibit isotropic properties or a different level of anisotropy. If isotropic properties are required, e.g. hot consolidation or forging can be applied. The application of extrusion process leads, in turn, to directional elongation of grains and, in consequence, to anisotropy. The level of anisotropy results mainly from extrusion ratio, as well as from extrusion velocity, temperature and friction conditions on metal-tool contact surface. Therefore, in case when a directional character of loading during the work of an element is expected, this manufacturing technology is a preferred choice. The proper selection of reinforcement is also an important problem. In case of aluminium-based composites, the introduction of ceramic fibres or whiskers will result in anisotropy. Isotropic material can be obtained through the introduction of ceramic phase particles, e.g. silicon carbide, into the matrix. Directional arrangement of continuous fibres in the matrix, e.g. through laminar locating alternately with powder layers, causes much stronger effect of the anisotropy of properties than that resulting from manufacturing of semi-finished products in the form of mixtures of metallic matrix powder and short fibres [2].

Summarizing, during the design of a composite, the character of work and working conditions of a final product should be foreseen. Considering the above, the choice of the variant of manufacturing technology, as well as type and volume fraction of reinforcing phase, will aim at obtaining the material showing the most favourable properties, from the point of view of foreseen working conditions such as expected loading scheme, friction conditions, possible wear etc.

\section{EXPERIMENT}

Objective. The objective of realized investigations was the evaluation of the effect of chemical composition, type of applied reinforcement and manufacturing method on selected properties of materials obtained by means of plastic forming of aluminium powder compacts and composite mixtures of Al powder with ceramic phase. Two methods were employed to materials forming: hot forging and hot extrusion. The subject to the manufacturing and subsequent testing were the materials without reinforcement as well as composites containing $5 \%$ volume fraction of reinforcing phase in the form of silicon carbide particles and alumina fibres.

Materials. As a matrix the atomized aluminium powder of a trade name RAl-1 was applied. The shape of powder particles is shown in Figure 1a. As a reinforcing phase the 
ceramic staple fibres of a trade name Belcotex, type 550 TEX, 8-10 $\mu$ m diameter (Fig. 1b) and approx. $12 \mathrm{~mm}$ average length, as well as silicon carbide particles $\mathrm{SiC}_{1000}$ (Fig. 1c) were applied. Chemical compositions of individual components are given in Table 1.
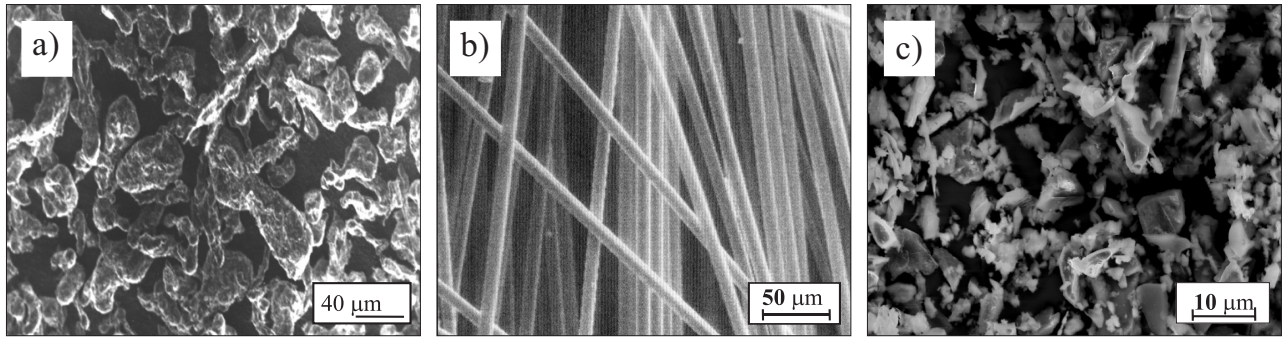

Fig. 1. Morphology of test materials: a) RAl-1 atomized aluminium powder; b) Belcotex ceramic fibres; c) silicon carbide particles $\mathrm{SiC}_{1000}$

Table 1. Chemical composition of test materials

\begin{tabular}{|c|c|c|c|c|c|c|c|c|}
\hline \multirow{2}{*}{$\begin{array}{l}\text { RAl-1 } \\
\text { powder }\end{array}$} & \multirow{2}{*}{ matrix } & component & $\mathrm{Fe}$ & $\mathrm{Si}$ & $\mathrm{Cu}$ & $\mathrm{Zn}$ & $\mathrm{Ti}$ & $\mathrm{Al}$ \\
\hline & & content, $\%$ & 0.2 & 0.3 & 0.02 & 0.06 & 0.03 & rem. \\
\hline \multirow{2}{*}{$\begin{array}{l}\text { Belcotex } \\
\text { fibres }\end{array}$} & \multirow{2}{*}{$\begin{array}{l}\text { reinforcing } \\
\text { phase }\end{array}$} & component & $\mathrm{Al}_{2} \mathrm{O}_{3}$ & $\mathrm{SiO}_{2}$ & $\mathrm{Na}_{2} \mathrm{O}$ & other & & \\
\hline & & content, \% & 94.5 & 4.5 & $<0.5$ & $<0.5$ & & \\
\hline \multirow{2}{*}{$\begin{array}{l}\mathrm{SiC}_{1000} \\
\text { particles }\end{array}$} & \multirow{2}{*}{$\begin{array}{l}\text { reinforcing } \\
\text { phase }\end{array}$} & component & $\mathrm{Fe}_{2} \mathrm{O}_{3}$ & $\mathrm{C}$ & $\mathrm{SiC}$ & & & \\
\hline & & content, $\%$ & 0.8 & 0.3 & rem. & & & \\
\hline
\end{tabular}

Preparation of materials. Aluminium powder and reinforcing phase in the form of ceramic particles or fibres were mixed using two-cone mixer. The weights of components were selected properly, in order to obtain mixtures containing 5\% volume fraction of reinforcing phase in the matrix powder. The mixing process was realized with constant speed of rotation of mixing chamber, which was equal to $0.9 \mathrm{~s}^{-1}$. The mixing time was selected depending on the type of reinforcing phase. Dry mixing was employed when preparing a mixture of aluminium powder and silicon carbide particles. In order to avoid formation of conglomerates, fibres were mixed in a suspension of $\mathrm{Al}$ powder in methanol. The mixtures prepared as described above, as well as aluminium powder, were subjected to cold compaction applying unit pressure which allowed to obtain compacts showing the density amounting to approx. $80 \%$ of that of a solid material.

The compacts were heated and then hot formed in plastic working processes. Closed-die forging and extrusion processes were applied. In both cases the deformation was realized in isothermal conditions, at the temperature of $500^{\circ} \mathrm{C}$. The compacts destined for forging were heated in a pipe furnace during 30 minutes, then transported to the heated die cavity and forged. The compacts to be extruded were heated directly inside the die. The 
process was realized applying the extrusion ratio $\lambda=4.11$ and velocity of $0.1 \mathrm{~mm} / \mathrm{s}$. The types and volume fraction of reinforcing phase, type of reinforcement and plastic working processes employed during forming of materials to be tested, are presented in Table 2.

Table 2. Chemical composition, manufacturing method and forming parameters of test materials

\begin{tabular}{|c|c|c|c|c|c|c|}
\hline No. & $\begin{array}{l}\text { Matrix } \\
\text { material }\end{array}$ & $\begin{array}{l}\text { Type of } \\
\text { reinforcing } \\
\text { phase }\end{array}$ & $\begin{array}{c}\text { Type of } \\
\text { reinforcement }\end{array}$ & $\begin{array}{c}\text { Reinforcing phase } \\
\text { volume fraction } \\
\%\end{array}$ & $\begin{array}{l}\text { Manufacturing } \\
\text { method }\end{array}$ & $\begin{array}{l}\text { Working } \\
\text { temperature } \\
{ }^{\circ} \mathrm{C}\end{array}$ \\
\hline 1 & \multirow{5}{*}{$\begin{array}{l}\text { atomized } \\
\text { aluminium } \\
\text { powder } \\
\text { RAl-1 }\end{array}$} & none & - & 0 & \multirow{3}{*}{$\begin{array}{c}\text { extrusion with } \\
\text { extrusion ratio } \\
\lambda=4.11\end{array}$} & \multirow{5}{*}{500} \\
\hline 2 & & $\mathrm{SiC}$ & particles & 5 & & \\
\hline 3 & & $\mathrm{Al}_{2} \mathrm{O}_{3}$ & staple fibres & 5 & & \\
\hline 4 & & none & - & 0 & \multirow{2}{*}{$\begin{array}{l}\text { closed-die } \\
\text { forging }\end{array}$} & \\
\hline 5 & & $\mathrm{SiC}$ & particles & 5 & & \\
\hline
\end{tabular}

For the obtained materials, their relative densities were determined, selected mechanical and functional properties were evaluated, and flow curves were constructed at ambient temperature as well as at elevated temperature $\left(200^{\circ} \mathrm{C}\right)$.

\section{RESULTS}

\subsection{Density testing}

The measurements of density of materials were performed applying Archimedes method, by measuring the weight of specimens in the air and in water. The obtained results are presented in Figure 2, for materials in the state after extrusion (2a) and after forging (2b), respectively.

a)

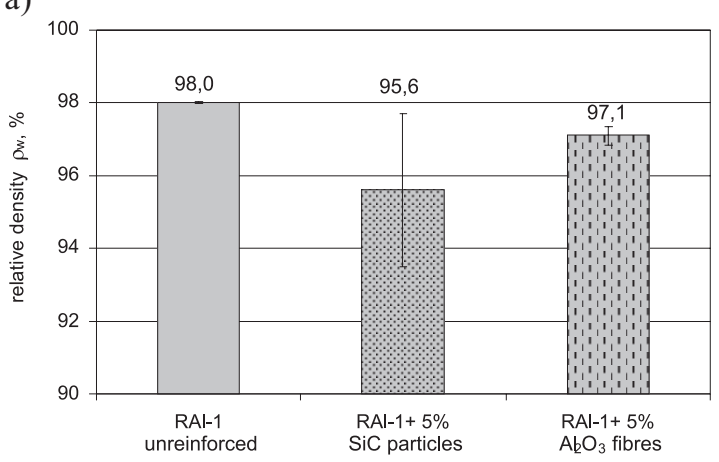

b)

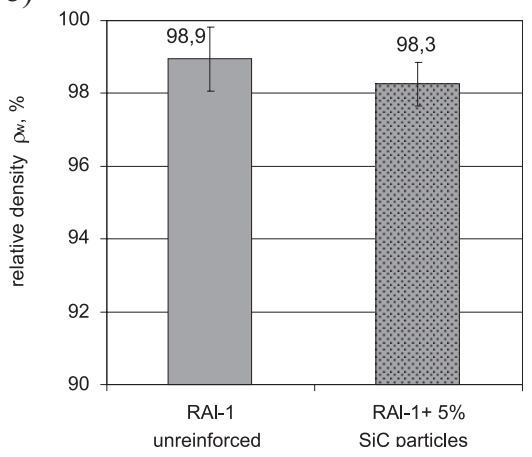

Fig. 2. The effect of manufacturing method and chemical composition on the relative density of materials obtained by means of forming of RAl-1 aluminium powder compacts and composite mixtures, at the temperature of $500^{\circ} \mathrm{C}$, in the following processes: a) extrusion with extrusion ratio $\lambda=4.11$; b) closed-die forging 
Basing on the obtained results of investigations it was found that the manufacturing of aluminium powder compacts or composite mixtures of $\mathrm{Al}$ powder with reinforcing ceramic phase, with application of plastic working processes, at the temperature of $500^{\circ} \mathrm{C}$, leads to obtaining highly compacted materials. In no case the volume fraction of pores in the materials being formed exceeded 5\%. The highest relative densities were obtained in case of aluminium without reinforcement, amounting to $98.00 \pm 0.87$ in the state after forging and $98.94 \pm 0.03$ after extrusion, respectively. The introduction of reinforcing phase into the matrix results in decrease of relative density, regardless of its type and applied manufacturing method. The densities of materials obtained by means of closed-die forging were slightly higher than those observed after extrusion.

\subsection{Mechanical properties of materials}

Hardness measurement. Brinell hardness number was determined in accordance with a standard. The results of hardness measurements of investigated materials are presented in Figure 3.

a)

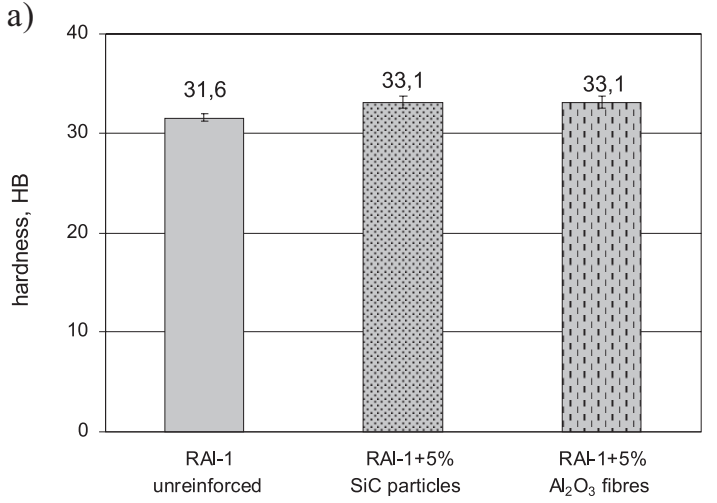

b)

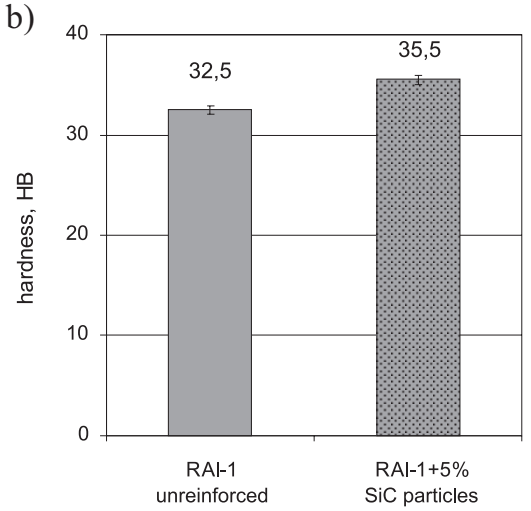

Fig. 3. Brinell hardness number of materials obtained by means of forming of RAl-1 aluminium powder compacts and composite mixtures, at the temperature of $500^{\circ} \mathrm{C}$, in the following processes: a) extrusion with extrusion ratio $\lambda=4.11$; b) closed-die forging

As a result of introduction of 5\% volume fraction of reinforcing phase into the aluminium matrix, only a slight increase of material's Brinell hardness number was observed, regardless of its type and applied manufacturing method. No significant differences were found between hardness of materials after forging and after extrusion.

Tensile test. Tensile strength of investigated materials was determined basing on the results obtained in uniaxial tensile test. The tests were performed with application of Instron 4502 testing machine, at ambient temperature and velocity of $1 \mathrm{~mm} / \mathrm{min}$. The results of investigations of the effect of manufacturing method and chemical composition on the tensile strength $\left(R_{m}\right)$ of analysed materials are shown in Figure 4. 

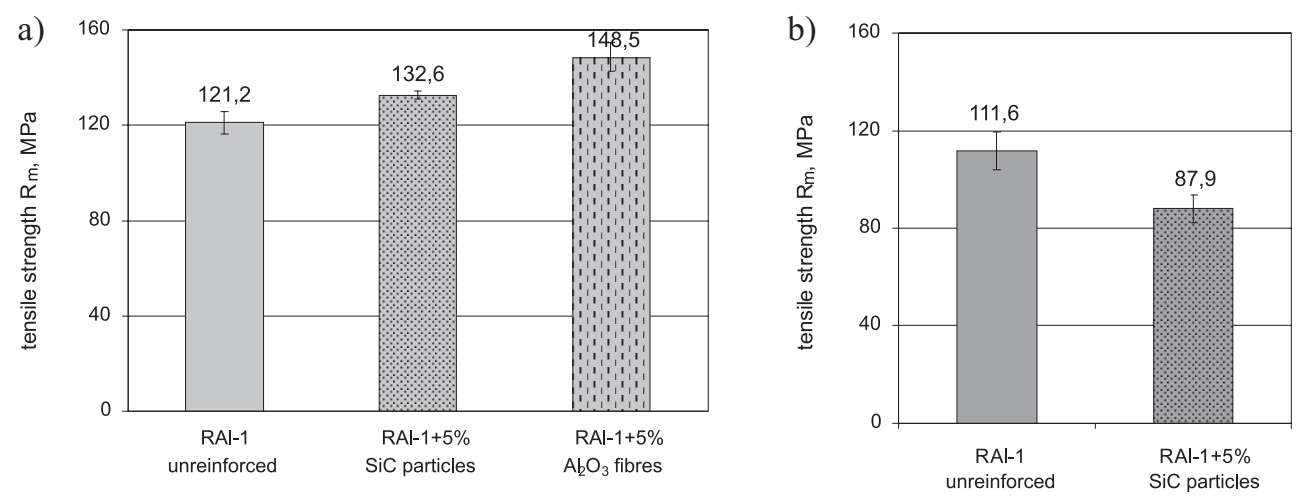

Fig. 4. Tensile strength $R_{m}$ of materials obtained by means of forming of RAl-1 aluminium powder compacts and composite mixtures, at the temperature of $500^{\circ} \mathrm{C}$, in the following processes: a) extrusion with extrusion ratio $\lambda=4.11$; b) closed-die forging

For the matrix material, the tensile strength of $121.2 \pm 4.8 \mathrm{MPa}$ was obtained in the state after extrusion and $111.6 \pm 7.7 \mathrm{MPa}$ after closed-die forging, respectively. The introduction of $5 \%$ volume fraction of silicon carbide particles into the matrix of extruded materials resulted in the increase of tensile strength by approx. $10 \%$, in relation to the material without reinforcement. As a result of reinforcing the same material with $5 \%$ volume fraction of Belcotex fibres, the tensile strength increased by approx. $22 \%$. In case of the composite produced in closed-die forging process, containing 5\% of silicon carbide particles, the decrease of $R_{m}$ was observed as compared with the matrix obtained with application of the same manufacturing method. The tensile strength value was equal to $87.9 \pm 6.1 \mathrm{MPa}$ and was lower by approx. $35 \%$ when compared with the material of the same chemical composition obtained by means of extrusion of compacts, applying $\lambda=4.11$ extrusion ratio.

\subsection{Stress-strain curves in compression}

The behaviour of non-reinforced materials and composites in the state after extrusion with $\lambda=4.11$ extrusion ratio as well as after closed-die forging, was analysed in uniaxial compression test. The specimens of height to diameter ratio equal to 1.2 were prepared for the tests. Compression tests were performed applying the strain rate of $0.01 \mathrm{~s}^{-1}$, at ambient temperature and at $200^{\circ} \mathrm{C}$. The displacement during deformation and corresponding load were measured. The system with automatic temperature control for the die and the specimen was applied. The registration of load and corresponding change of specimen dimensions was realized with $25 \mathrm{~Hz}$ frequency. The relationships of true stress $\left(\sigma_{\text {effective }}\right)$ ? as a function of strain $(\varepsilon)$, constructed basing on the results of compression test for the matrix and the composites, are presented for extruded materials in Figure 5a and for materials after closed-die forging in Figure 5b.

It was found that the introduction of 5\% volume fraction of reinforcing ceramic phase into the matrix results in the increase of stresses required to realize a given strain, regardless of the type of reinforcing phase, applied manufacturing method and test temperature. The highest strain hardening during compression tests, performed at both ambient temperature 
and $200^{\circ} \mathrm{C}$, was obtained in the composite containing $5 \%$ of Belcotex fibres, in the state after hot extrusion. In case of this composite the character of stress-strain curve at $200^{\circ} \mathrm{C}$ was comparable with the curve constructed for non-reinforced matrix at ambient temperature. The introduction of silicon carbide particles into aluminium matrix caused its relatively lower strain hardening. The investigated materials underwent plastic deformation during compression at both test temperatures, and in no case the cohesion of specimens was impaired. The character of stress-strain curves for matrix material was comparable for materials obtained by means of both closed-die forging and extrusion. The same tendency was observed in case of composites containing 5\% volume fraction of silicon carbide particles.
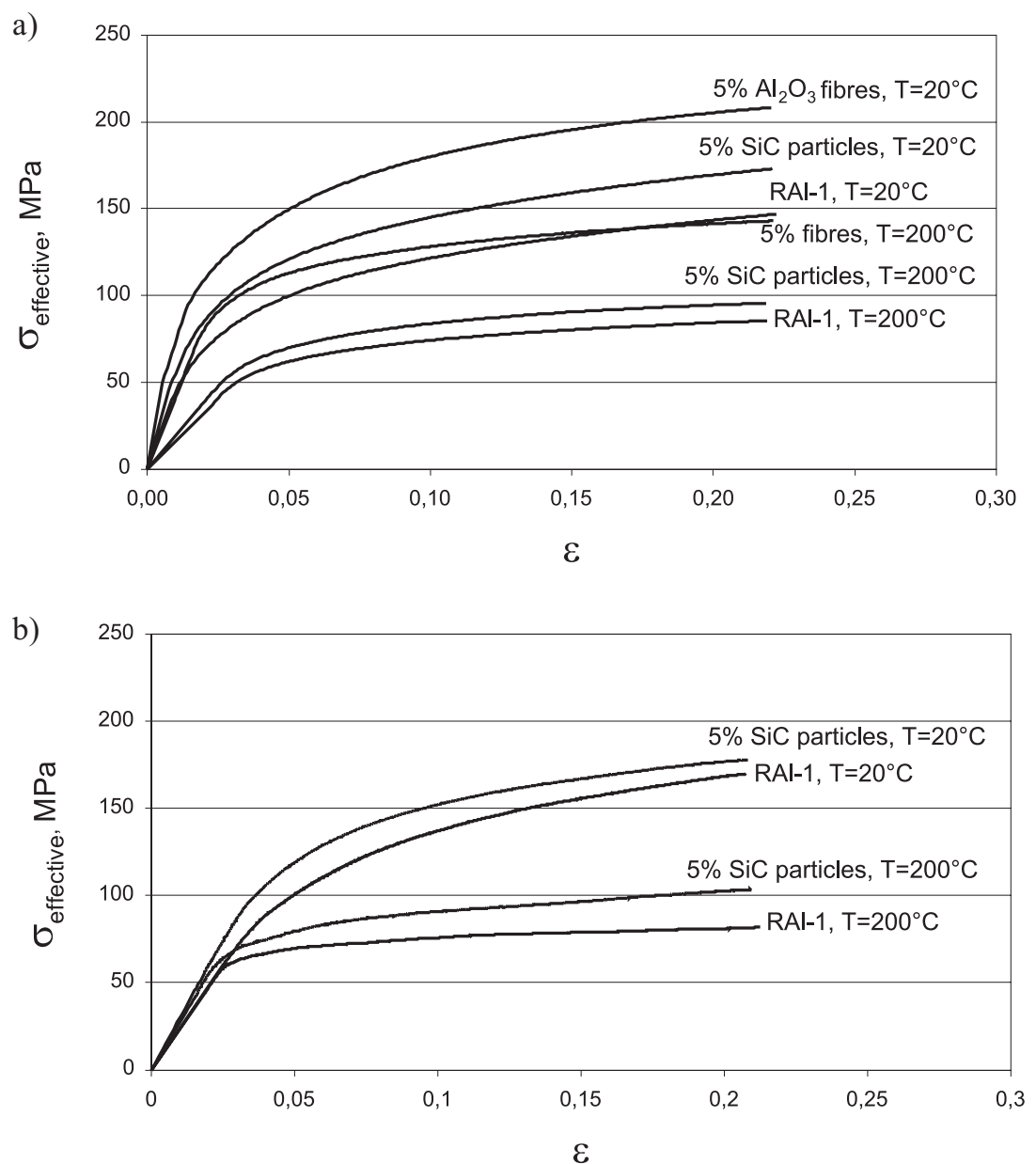

Fig. 5. Stress-strain curves obtained in compression test at the temperatures $20^{\circ} \mathrm{C}$ and $200^{\circ} \mathrm{C}$ for materials obtained by means of forming of RAl-1 aluminium powder compacts and composite mixtures, at the temperature of $500^{\circ} \mathrm{C}$, in the following processes: a) extrusion with extrusion ratio $\lambda=4.11 ; b)$ closed-die forging 


\subsection{Wear resistance testing}

Comparative testing of abrasive wear of investigated materials was performed on a test stand located in the Department of Surface Engineering \& Materials Characterisation at AGH-UST. As a counter-specimen the disk of 68 HRC hardness was applied. The abrasion was realized at the velocity of $0.3 \mathrm{~m} / \mathrm{s}$, with the path length of $2000 \mathrm{~m}$ and with $20 \mathrm{~N}$ load applied on the specimen. The weights of specimens were measured before starting the test and after completing it. This allowed to determine the loss in volume of materials as a result of abrasive wear. The obtained results are presented in Figure 6.
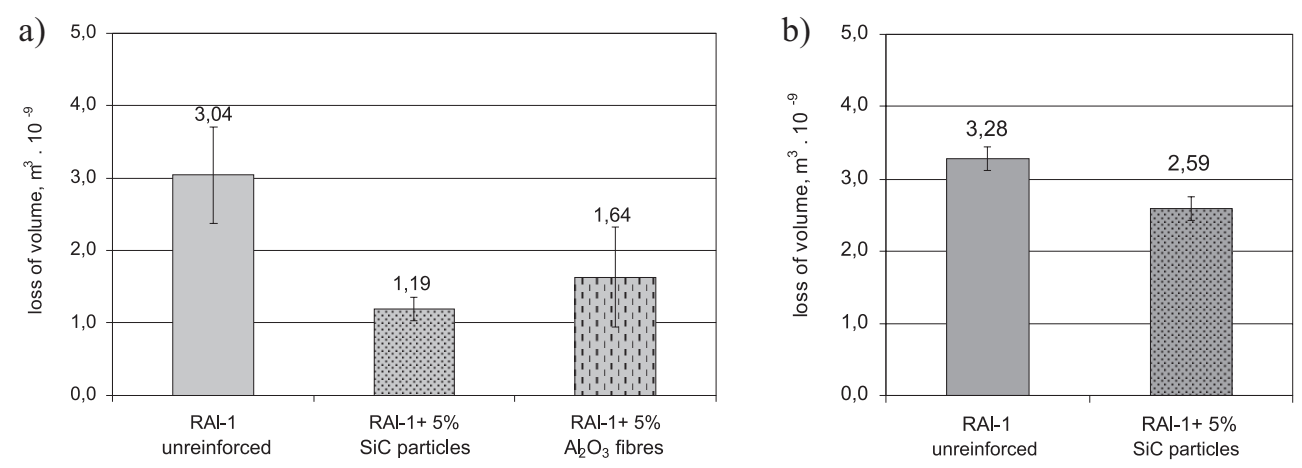

Fig. 6. Abrasive wear of materials obtained by means of forming of RAl-1 aluminium powder compacts and composite mixtures, at the temperature of $500^{\circ} \mathrm{C}$, in the following processes: a) extrusion with extrusion ratio $\lambda=4.11$; b) closed-die forging

At the given conditions of test realization, the lowest wear amounting to $1.19 \mathrm{~m}^{3} \cdot 10^{-9}$ was shown by composite containing $5 \%$ volume fraction of silicon carbide particles, extruded at the temperature of $500^{\circ} \mathrm{C}$. The abrasive wear of forged materials was higher in comparison with that of extruded materials of the same chemical composition. The highest wear amounting to $3.28 \mathrm{~m}^{3} \cdot 10^{-9}$ was shown by non-reinforced matrix in the state after closed-die forging, and it was by approx. $8 \%$ higher than in case of the same material after extrusion with the extrusion ratio $\lambda=4.11$. The introduction of $5 \%$ of silicon carbide particles into the matrix caused the decrease of wear in case of both manufacturing methods, as much as to $79 \%$ for closed-die-forged materials and to $39 \%$ for extruded ones, respectively. Extruded composite containing 5\% volume fraction of Belcotex fibres showed the wear lower by $45 \%$, when compared with non-reinforced material obtained in the same forming process.

In order to compare the obtained results qualitatively, the analysis of relative values of abrasive wear for all investigated materials was performed. The loss in volume of a material exhibiting the lowest wear resistance, as it was shown in the tests, was assumed to be $100 \%$ wear. Relative values of abrasive wear for all investigated materials are presented in Figure 7. 


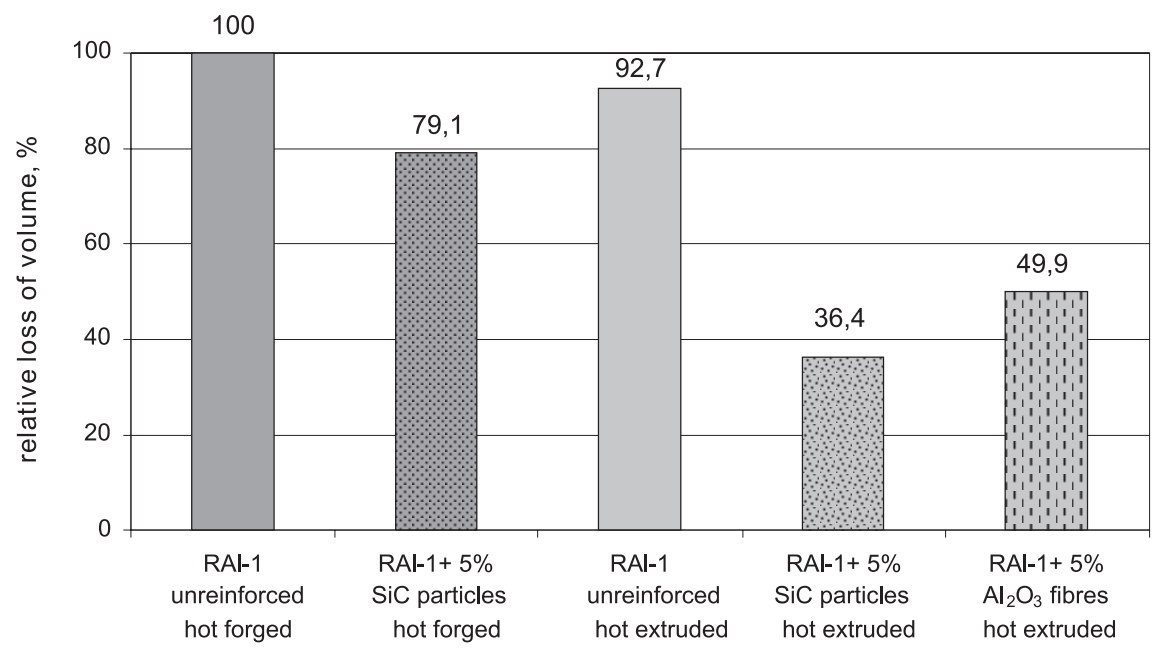

Fig. 7. The effect of manufacturing method and chemical composition on the relative abrasive wear of materials obtained by means of forming of RAl-1 aluminium powder compacts and composite mixtures, at the temperature of $500^{\circ} \mathrm{C}$, in the following processes: a) extrusion with extrusion ratio $\lambda=4.11 ; b)$ closed-die forging

\section{DISCUSSION OF THE RESULTS}

Basing on the results of investigations of the effect of manufacturing method and chemical composition of RAl-1 aluminium powder compacts and composite mixtures on selected properties of materials obtained in the extrusion process realized with extrusion ratio $\lambda=4.11$ as well as in the closed-die forging process, both realized at the temperature of $500^{\circ} \mathrm{C}$, it was found that these technologies allow to produce highly compacted materials. Relative densities of extruded materials were slightly lower as compared with forged materials of the same chemical composition. However, no significant differences were found in consolidation level. In no case the porosity of tested specimens exceeded $5 \%$ volume fraction, i.e. the value specified as a limit for structural components.

The lack of correlation between hardness and strength of materials is connected probably with the behaviour of reinforcing phase during hardness measurement. As a result of indentation, the deformation of a soft matrix takes place. Particles or fibres introduced into the matrix also undergo a displacement, thus not affecting significantly the level of Brinell hardness number. On the other hand, during the realization of tensile test, compression test and wear resistance testing, the reinforcing ceramic phase transmits the applied load and contributes actively to strengthening of the matrix, thus resulting in considerable changes of investigated properties.

Basing on the results of performed comparative test, the lowest abrasive wear was observed for extruded composite containing 5\% of silicon carbide particles, which probably results from higher hardness of this phase when compared with Belcotex fibres. In case of forged composites of the same chemical composition, the abrasive wear is only slightly 
lower than that shown by the matrix and more than twice as high as that observed after extrusion. Considering the fact that hardness of the matrix of both forged and extruded materials is comparable, it may be assumed that in case of forged material the silicon carbide particles are more loosely located in the matrix and thus are more susceptible to be torn off during wear resistance testing. Additionally, loose particles influence the test result, since their presence between friction surfaces causes the intensification of abrasion of the matrix. The extrusion of compacts with extrusion ratio $\lambda=4.11$ leads to obtaining higher properties than in case of forming by means of closed-die forging. The type of applied reinforcing ceramic phase depends on the required material properties and the expected working conditions of a final product. In case when high mechanical properties are required, e.g. high tensile strength or strength at elevated working temperatures, Belcotex fibres as a reinforcement is a proper choice. Higher wear resistance can be achieved by the introduction of silicon carbide particles into the matrix.

In the light of results of realized investigations concerning the properties of aluminium-based materials reinforced with ceramic phase, it was confirmed that the proposed manufacturing technology leads to obtaining highly compacted products showing the mechanical and functional properties which allow to use them in structural components. Depending on requirements resulting from the expected application of materials, these properties can be controlled by means of proper selection of the type of reinforcing phase and manufacturing method.

\section{REFERENCES}

[1] Strainer L.G.: Optimisation of the wet lay up / vacuum bag process for CRFP composites. Composites, $1989,20,5,441-449$

[2] Wojtaszek M.: Wpływ kształtowania na gorąco na własności kompozytów aluminiowych umocnionych włóknami ceramicznymi. Praca doktorska, AGH Kraków, 2000

[3] Wojtaszek M., Szczepanik S.: Wybrane własności wstępnie zagęszczanych i wyciskanych na goraco tworzyw z proszku stopu Al-Si-Fe-Cu i kompozytu umocnionego cząstkami SiC. Mat. konf. „Polska Metalurgia w latach 2002-2006”, Komitet Metalurgii PAN, red. K. Świątkowski, 501-506

[4] Wojtaszek M., Szczepanik S.: Wybrane własności kompozytów aluminium - cząstki węglika krzemu otrzymanych z proszków w procesie kucia na gorąco i po odkształcaniu na zimno. Kompozyty, 5 (2005) 3, 70-76

[5] Kök M., Özdin K.: Wear resistance of aluminium alloy and its composites reinforced by $\mathrm{Al}_{2} \mathrm{O}_{3}$ particles. Journal of Materials Processing Technology, 183 (2007), 301-307

[6] Narayan M., Surappa M.K., Bai B.N.P.: Dry sliding wear of $\mathrm{Al}$ alloy $\mathrm{Al}_{2} \mathrm{O}_{3}$ particles metal matrix composites, Wear 182-183, 1995, 563-570

[7] Tjong S.C., Ma Z.Y: High-temperature creep behaviour of powder-metallurgy aluminium composites reinforced with $\mathrm{SiC}$ particles of various sizes. Composites Science and Technology, 59 (1999), 1117-1125

[8] Sobczak J.: Metalowe materiały kompozytowe. Stan aktualny i perspektywy rozwoju w świetle polityki naukowej, technologii i praktyki przemysłowej Stanów Zjednoczonych. Instytut Odlewnictwa, Kraków 1996 